\title{
Flat-Rate versus Progressive Taxation? An Impact Evaluation Study for the Case of Romania
}

\author{
Madalina Ecaterina Popescu $1,2, * \mathbb{C}$, Eva Militaru ${ }^{1}$, Larisa Stanila ${ }^{1}$, Maria Denisa Vasilescu ${ }^{1,2}$ \\ and Amalia Cristescu 1,3 \\ 1 National Scientific Research Institute for Labor and Social Protection, 010643 Bucharest, Romania; \\ militaru@incsmps.ro (E.M.); larisa.stanila@incsmps.ro (L.S.); mariadenisa.vasilescu@gmail.com (M.D.V.); \\ cristescuamalia@gmail.com (A.C.) \\ 2 The Faculty of Economic Cybernetics, Statistics and Informatics, The Bucharest University of Economic \\ Studies, 010552 Bucharest, Romania \\ 3 The Faculty of Theoretical and Applied Economics, The Bucharest University of Economic Studies, \\ 010552 Bucharest, Romania \\ * Correspondence: madalina.andreica@csie.ase.ro
}

Received: 4 October 2019; Accepted: 9 November 2019; Published: 14 November 2019

\begin{abstract}
Taking into consideration the recent debates on adopting a progressive tax system over the flat-rate taxation, our paper aims to investigate the impact of a change in the current Romanian personal income tax policy system from the $10 \%$ flat-rate tax system to some alternative progressive taxation scenarios. The methodological approach consisted in using the European Union Survey on Income and Living Conditions (EU-SILC) database to micro-simulate the impact upon poverty and income inequality. Through our ex-ante tax policy analysis we bring empirical evidence of a modest, but positive effect upon poverty rate and income inequalities in favor of a progressive taxation system. However, when looking at the government financial implications through the personal income tax budget revenues, we discuss upon the possible trade-off between the benefits on poverty and income inequalities and the possible budgetary drawbacks. Despite the data limitations, this study has the benefit of being among the first attempts to evaluate the impact of a personal income tax policy reform for the case of Romania.
\end{abstract}

Keywords: flat-rate taxation; progressive taxation; income inequality; poverty rate; budget revenues; policy impact evaluation

\section{Introduction}

Assuring a fair tax burden distribution among people has been a central concern in policy-making for such a long time. A proper tax system should maximize the social welfare function under a government budget constraint, while considering that the social welfare is greater when resources are more equally distributed. Yet, the redistribution of taxes and transfers could negatively affect the desire to work and/or save, which further creates a trade-off between equity and efficiency. In this respect, the very high earners should have high and rising marginal tax rates on earnings, while the earnings of low-income families should be subsidized (mainly because the low earners' decisions are whether to participate in labor markets or not). Taking into account all of the above, the results indicate that the optimal profile of transfers and taxes is highly nonlinear and it is very difficult to be well approximated by a flat tax [1].

The discussion about taxation is generally on the two effects that appear: the income effect and the substitution effect. High taxes lead to diminishing the disposable income of an individual, which in turn could compensate for this "loss" through more hours worked (the income effect). On the other 
hand, a high marginal tax rate could drive the individual to prefer leisure instead of work, if the extra hours did not bring a substantial surplus to the income (substitution effect, which can be considered as an indicator of economic inefficiency) [2].

The progressive taxation and the benefits of social insurance aim to improve the situation of the poorest individuals in a society. Moreover, the fairness of a tax system should also be considered (fair and equal treatment of members as poor or rich-the horizontal equity criterion), in addition to the redistribution effect between the rich and the poor (vertical redistribution effect).

Apart from being fair and efficient, a good tax system should also be coherent, simple, and easy to implement. In other words, the tax payer must fully understand it and know what is taxed or not (for example, in the case of income tax, it must be clear what is included in the income and what goes into capital gains). A good tax system must also be flexible and stable. The flexibility is mainly needed for political reasons, while the stability is needed for economic reasons.

Although the structure of taxes can be a problem for the governments of each country, as the national economies are mostly open economies, any decision can have an impact on the economy from the perspective of relations with other countries. The constraints that appear in this area are not so much in the form of the fiscal strategy, as in the level and distribution of the fiscal burden. The more extensive international economic and financial relations become, the more important it is for national governments not to derail the national tax system [2]. Any significant movement of capital or persons with certain training to countries with a more friendly fiscal system can lead to an economic decline.

In general, a proper income tax system can play the role of an effective tool in combating income inequality, which is often considered to have negative effects on economic sustainability. Moreover, the 2030 Agenda for Sustainable Development [3] has made an important goal of reducing inequalities and providing decent work for all, positioning them at the center of the policies designed for sustainable growth and development. ILO (International Labour Organization) considers that decent work, with all its implications, including reducing inequalities, is not just a goal, but a "driver of sustainable development". The major argument is that by increasing employment and reducing inequalities, more people will have a greater purchasing power, fueling the growth and the development of sustainable enterprises.

Among the types of taxation systems, progressive taxation is known to be the most popular measure for reducing income inequality, while the flat-rate tax regime is usually criticized for failing to reduce income inequalities. Although the income inequalities in the European Union Member States are relatively small compared to other developed countries, the importance of reducing inequalities is very high in the context of ensuring the well-being of the EU citizens. An increased level of income inequality can have negative effects on the economy, resulting in a low level of aggregate demand, low investments in human capital, low labor productivity, inefficient allocation of resources, all of which significantly slow down economic growth [4]. After the Great Recession, there has been considerable pressure exerted on the social protection systems at the European level. The degree of inequality has increased in most European states, raising concerns both from the sustainable economic growth perspective, as well as from the social cohesion point of view. The crisis has had strong effects, not only on the economic and financial level, but also on the social and even psychological level, with a strong impact on further development, as the attitude of fear and mistrust hampers economic growth [5]. There are also concerns about the inclusive nature of economic growth, particularly when a country's total income grows faster than its households' incomes, making the economic growth less conducive to inclusion and its benefits less notable at the household level.

The 2018 Annual Growth Survey of the European Commission highlighted the importance of the tax system in terms of stimulating economic growth and reducing income inequalities. In order to ensure inclusive economic growth, which will equally benefit the individuals on each side of the income distribution, measures to stimulate economic growth, as well as those aimed at equity in society, must be targeted [6]. These considerations become especially important when it comes to reforming the tax system-the main tool that policy makers have for reducing inequalities. 
The tax systems used by the EU Member States are different from several points of view. Some states use progressive taxation, meant to shift the tax burden from those with relatively low incomes to those with high incomes, thus creating the context of social justice [7]. In general, the degree of progressivity in Europe is on a clear downward trend both in the number of brackets and in the top marginal tax rate [8]. Progressive taxation is generally specific to economically developed countries. The essential economic reason is that it acts as an automatic counter-cyclical regulator of the respective economies. When the economy grows and the revenues increase, a share of the revenue growth is returned to the state, which has two notable advantages: firstly, it limits the too-rapid growth of the aggregate demand which, in turn, impedes price increases and secondly, it reduces the public deficit during the economic boom periods. It should be noted, however, that the role of counter-cyclical regulator is manifested if and only if the governments have responsible behavior and refrain from committing additional spending during the boom periods; otherwise, both benefits immediately disappear. In comparison to progressive taxation, the flat tax system has been introduced mainly in transitioning states. The benefits of this system are generally related to simplicity, higher payer compliance and lower effects on distorting economic growth and employment [9]. These arguments were also the most used at the time when this tax system was introduced in the Central and Eastern European countries between 1990 and 2005. However, given the fact that income inequalities are increasing in these states, the question of introducing a progressive tax system is raised.

Among the Central and Eastern European countries recently debating on adopting a progressive tax system over a flat tax, one is the case of Romania. In recent years, the dispute regarding the advantages and shortcomings of the two tax systems has come to the public's attention in Romania. The flat tax system imposes a manifestation of the principle of equality against taxes, maintaining a constant income-tax ratio, but at the same time it violates the principles of fiscal equity, because it does not take into account that the contributory power rises with the income increase of different social categories. The progressive tax system respects the principles of fiscal equity only if it is combined with the global income taxation system, regardless of the source of origin.

In Romania, both flat-rate and progressive personal income taxation systems were used. Both systems have advantages and disadvantages, and the balance between equity and efficiency can only be achieved through a fiscal policy adapted to each economy and whose measures are evaluated ex-ante. On the other hand, any change in the tax rate, either directly (flat rate) or indirectly (VAT (Value-Added Tax) rate), has to be made on the basis of a cost-benefit analysis, so that the impact on the main macroeconomic indicators can be identified, including the budget deficit. The change of a tax system is recommended to be done in calm economic periods, or possibly even in periods of economic growth. The pro-cyclicality of the fiscal policy only creates a vicious circle at the level of any economy, so that if during the recession period indirect tax increases (especially VAT) and reductions in the public sector incomes are needed, the negative effects of these measures will be cumulative and will have an unexpected short-term result, by reducing the state budget revenues determined by the reduction of the tax base and tax evasion. Clearly, the efficiency of fiscal policy measures is conditioned by several factors, including: The legislative stability that makes the predictability of any economic action possible, the application of a fair tax system for all taxpayers, the reform of the fiscal system, the reduction and the efficient management of the budgetary expenses, and laying the foundation of impact assessments for all fiscal measures.

Since 1990, Romania has undergone a period of major changes in order to move from communism to a capitalist economy, and the tax system, among others, has undergone a series of reforms. The period of 1990-2005 was characterized by a progressive taxation system with rates between $18 \%$ and $40 \%$. From an economic point of view, this taxation system was adapted to the needs of that period-it ensured fiscal equity, a balanced distribution and redistribution of incomes and a non-accelerated economic growth [10].

In 2005, a 16\% flat-rate tax system was implemented, having the stated purpose of encouraging the business environment, stimulating consumption and foreign investments, reducing tax evasion, 
and stimulating economic growth [10]. The main reason for the criticism of flat-rate taxation was in relation to its unfairness from the perspective of social justice, but also from the perspective of low revenues to the state budget (as a percentage of GDP). One of the arguments in favor of flat rate taxation was the reduction of tax evasion, so low budget revenues are considered a failure from this point of view. On the other hand, the increase of the tax collection efficiency can be achieved through the development of the fiscal authority and not necessarily through important changes of the tax system [11]. For the period of economic crisis, the authors in [12] concluded that the government fiscal policy was sustainable in the short term in relation to the sovereign debt, but in the long term the sustainability would be maintained if the economic growth rates were around $5 \%$ and the budget deficits below $3 \%$.

New changes took place in 2018 when the personal income tax rate was reduced to $10 \%$ and social contributions were moved from the employer to entirely the employee's responsibility. Although the EU member states are free in the design and implementation of tax systems, only Romania and Lithuania use the practice of making social system contributions the employee's burden. At the European Union level, Romania has the lowest top statutory personal income tax rates, next to Bulgaria (10\%): the average EU-28 rate is $39.4 \%$ whereas in Sweden the top statutory personal income tax rate is $57.2 \%$ - the highest level in the EU [13].

The multiple changes of the fiscal system (both direct and indirect taxes) in recent years have affected the Romanian economic environment, the perception of instability and uncertainty having numerous negative implications. Rapid changes indicate a lack of coherence that greatly affects the investment behavior, the climate of instability has an effect even at an international level, the failure to comply with fiscal principles can lead to increased tax evasion and the adoption of measures without a thorough impact analysis can affect both taxpayers, as well as budget revenues [14]. A study on Albania's fiscal policy has drawn attention to numerous tax changes and the effects on the economy: The personal income tax has changed on average every 2.8 years, and these rapid changes have been shown to have a negative impact on the performance of collecting taxes [15].

In terms of inequality and poverty, Romania still has the highest rate of poverty risk in the European Union, and economic and social inequality remains high compared to the European average. Inequality in Romania, as well as employment, income, and production also have a strong geographical dimension, as there are great differences between certain regions, between the capital and other counties [16], between large and small cities, and between the urban and rural areas, reflecting the tendency of agglomeration of resources in highly populated areas [17]. At the same time, inequality disproportionately affects different groups of people according to age, gender, and ethnicity. The high level of inequality is also caused by the diminishing redistributive effects of the tax system and is accentuated by the large differences existing between the incomes of the social classes, given that the richest $20 \%$ of the Romanians earn eight times more than the poorest $20 \%$ [18].

Reducing inequality and poverty, as well as the process of social inclusion, requires a series of multidimensional measures and actions [19]. The National Strategy for Romania's Sustainable Development 2030 addresses the reduction of social polarization through the gradual and constant increase of the incomes of the poor, the support of economic activities in rural areas, as well as the reduction in unemployment, social protection, and fiscal policy adjustments in order to improve the equality between citizens and to reduce the economic and social gaps between Romania and the EU average.

Having these in consideration, our paper aims to investigate the impact of a change in the current Romanian personal income tax policy system from the current $10 \%$ flat-rate tax system to one of two possible alternative progressive taxation scenarios. The contribution of our paper is threefold. First, we propose a novel methodological approach for the case of Romania that allows conducting an impact evaluation study in order to shed some light upon the main advantages and challenges of such tax policy. Annual micro-data collected through the European Union Survey on Income and Living Conditions (EU-SILC) is used in order to conduct the micro-simulations. Being among the 
first attempts to evaluate the impact of a personal income tax policy reform for the case of Romania, our empirical study should be seen as a pioneer in the field. Secondly, we focus on the main income tax policy's implications upon poverty and income inequality and bring evidence in favor of the progressive taxation system. Thirdly, we look at the government financial implications through the personal income tax budget revenues, and discuss upon the possible trade-off between the benefits on poverty and income inequalities and the possible budgetary drawbacks.

The paper is structured as follows: Section 2 is dedicated to the literature review in the field, where we emphasize on both the pros and cons brought by a flat-rate versus a progressive taxation system. The data and the simulation methodology are described in Section 3, while the main results of the impact evaluation analysis of progressive taxation system versus the current flat-rate tax system are presented in Section 4. The last section is dedicated to the discussions and the concluding remarks of the paper.

\section{Literature Review}

In recent decades there have been a large number of studies highlighting the importance of an adequate tax system in stimulating economic growth and reducing income inequalities, as changes in the tax and benefit system have an immediate effect. At the European level, the capacity of the tax and benefit system to counteract the increase of income inequality has decreased in recent years. In some countries, the tightness of the budget leverage and the need to restore the sustainability of public finances have reduced the state's ability to redistribute revenues. Therefore, more and more countries are now debating the benefits and drawbacks of progressive taxation over the flat-rate tax system.

In the literature there are a number of advantages and disadvantages of progressive taxation. Conesa and Krueger [20] argue that the use of progressive taxation can contribute to a more equal distribution of income, which will lead to a more equal distribution of consumption, as well as wealth and general welfare. On the other hand, they draw attention to the possible adverse effects of progressive taxation, as well as to the fact that in practice they are particularly difficult to estimate and mitigate. By far, the most important and often mentioned advantage of progressive taxation is the one related to the effect on income distribution. Shapiro [21] concluded that progressive taxation leads to much better fulfilment of the objective of social justice, considering that the people with a low level of income are taxed less than the rich ones, which leads to the improvement of the living conditions for the individuals at the bottom of the distribution.

Oishi et al. [22] analyzed the effect of progressive taxation on income inequality and happiness of Americans, using data for the period 1962 to 2014. Their results indicated that income inequality was significantly smaller in the periods when the income tax was more progressive, even if they controlled for variables like stock market performance or unemployment rate. Furthermore they obtained that higher progressive taxation is associated with lower income inequality in the forthcoming years.

Recent work has revealed another benefit of progressive taxation-the fact that it acts as a stabilizer $[23,24]$. In recessionary periods, individuals move into lower income brackets, with reduced average tax rates, while in periods of expansion the effect is reversed, so that through a progressive taxation system higher taxation revenues are collected from individuals in favorable economic periods, whereas during the crisis the taxation is milder. In this way, progressive taxation behaves like an automatic stabilizer, having two important effects: The disposable income becomes more stable over time, regardless of the economic cycles, and the volatility of hours worked is reduced. These effects lead to a much more stable GDP due to progressive taxation.

The disadvantages of progressive taxation are related to the fact that it affects incentives to work: Higher incomes imply higher taxes. Also, a progressive tax system is more difficult to implement, being more complicated as there are more tax brackets, thus determining higher administrative costs [25]. At the same time, the degree of progressivity is difficult to establish, as there is no consensus on what is good, fair, or optimal. So, for the majority of the time, when introducing a progressive tax system, the level of income inequality is used as an indicator: The more pronounced the income inequality, 
the more progressive the taxation is [7]. Other frequent criticisms in the literature on progressive taxation are that higher taxes applied to top-of-the-range income have adverse effects on growth and employment, and that progressive taxation is associated with higher tax evasion [26].

However, there are numerous studies that argue that these effects are not very intense (see for instance $[27,28]$, among others). With regard to the household sector, the most important adverse effects of progressive taxation are related to labor supply, saving behavior and the avoidance of paying taxes. The main argument against progressive taxation is that an increase in taxes leads to a reduction of the hourly compensation of work and thus reduces the opportunity cost of leisure. Salanié [29] argues that this effect (of substitution) is not certain, on the contrary, the effect of income may appear-the individual may work harder to compensate for the loss of income from taxes. In a meta-study on the wage elasticity of labor supply, Evers et al. [30] concluded that, on average, the elasticity among men is 0.07 , and among women is 0.34 . The much greater sensitivity of women to wage changes can be explained by the fact that women are still involved in household chores (unpaid work) much more than men and, especially in countries where the costs of childcare are high, women are more likely to work part time [31]. In general, the negative impact of higher taxes is mainly felt by vulnerable groups, characterized by a greater elasticity of labor supply. Thus, the maximum effect of progressive taxation can be obtained by lowering taxes among vulnerable groups. At the opposite end, at higher levels of income, the negative effects of higher taxes are reduced because labor supply elasticity is lower and the fixed cost of labor market participation is also much lower [4].

The negative effect of progressive taxation on economic growth is obvious within neoclassical microeconomic tax theory. However if we look from the perspective of Keynesian macroeconomics, it can be viewed differently. Keynes assumes that private consumption is directly related to disposable income. At the same time, there is a negative relationship between the degree of income inequality and private consumption-increasing inequality would lead to a decrease in private consumption. Thus, a correction (through taxation) of income distribution disparities would lead to an increase in private consumption, consequently stimulating economic growth [26]. Alternatively, an increase in the state budget revenues due to progressive taxation could be used to finance various government expenditures, also leading to economic growth [32].

The flat-rate tax system also has advantages and disadvantages. The main advantages mentioned in the literature are: a flat rate is simple, easy to understand, and cheap to implement in terms of administrative costs [33]; it equally affects tax payers, which can be perceived as a measure that respects the freedom of the individual [21]; the use of flat-rate taxation is associated with fewer cases of tax evasion [34]; applying a uniform rate for all workers is considered an incentive to work and earn more, with positive effects on productivity [7]. As main disadvantage, the authors in [34] assert that flat-rate taxation results in a relatively higher tax burden on low-income individuals, resulting in a negative effect on social justice and an increase in income inequality. Paulus et al. [35] have used EUROMOD to simulate different flat tax scenarios for Hungary and Slovenia; their results indicated that the introduction of a flat tax scheme would lead to a significant increase in the tax burden on the bottom deciles, generating an increase of inequality and poverty in both countries.

Of course, choosing a tax system-flat-rate or progressive-is a very important decision from many points of view. According to [36] the decision must take into account the fundamental economic problems specific to the country in question, such as the magnitude of income inequalities or the behavior of tax payers. For example, [37] analyzed the tax systems of 189 countries from 1981 to 2005, concluding that in developed countries there is a direct and strong link between the tax rates and the budget revenues collected from taxes, while this relationship is much weaker in countries with a low level of economic development and less consolidated institutions.

Rogers and Philippe [9] show that the states with a flat tax regime apply, on average, higher taxes on employees than those states with progressive taxation. According to the analysis, governments applying a flat tax continued in 2019 to tax workers at rates higher than those that implemented a progressive tax. Thus, the total real rate of taxation in the case of states with a flat-rate tax was, on 
average, $45.58 \%$ of the gross salary, compared with $44.52 \%$ of the total real rate of taxation in the states that have a progressive tax. In general, the flat-rate tax policy imposes a fixed rate of income taxation, the lowest in the EU being in Romania and Bulgaria, of $10 \%$. In contrast, in these countries social contributions are higher than in progressive systems. On average, social contributions are worth $72 \%$ of the total wage taxes collected in the flat-rate states. The study also determines the "tax liberation day" which measures how much an employee works each year to pay taxes. Thus, June 19 is for Romanian employees "the tax liberation day", when they escape the burden of taxes, they have to pay to the state for one year. This date places Romania on the 17th position in the EU in the ranking of tax liberation, considering that the citizens of Cyprus, Malta and Ireland pay their taxes to the state the fastest, on March 27, respectively April 19 and April 26, and the last are the people in Austria, Belgium and France, on July 18, 27, and 29.

From the international empirical studies, we conclude that when debating upon adopting a progressive tax system, one should consider, among other aspects, the effects upon income inequality, since inequalities are often seen to have a negative effect on economic growth. In general, the main drivers of inequality are: technological change and globalization which partly explain recent trends in labor income inequality [38-40], structural policies (policies in areas like education, labor market, product market [41]), taxes and transfers influencing the distributional outcomes [42], as well as tax expenditures [42]. Labor income also contributes to the increase in inequality, [43] showing that wages played a major role in the increase of the top $1 \%$ share and emphasizing the role of what they call the "working rich" (that part of a population of individuals that earns such high wages that they reach the top of the wealth distribution with no other sources of incomes). [44] studied an example of a "working rich" population from France, namely the financial industry, showing that the financial sector contributed to $48 \%$ and to $57 \%$ of the rise of the top $0.1 \%$ and top $0.01 \%$ income shares between 1996 and 2007.

If a country would propose to obtain pro-poor growth, this should be accompanied with a reduction of poverty and inequality. [45,46] observed that in OECD (Organisation for Economic Co-operation and Development) countries, after taxes and transfers poverty was $55 \%$ lower than before taxes and transfers. In the case of the United States, [47] argues that the federal tax system has little effect on overall inequality, but larger effects on poverty, concluding that the concern with the distribution of tax policies should rather be the effect on welfare.

The study of the Lithuanian Free Market Institute [28] analyzed the evolution of income inequalities for the period of 2007-2017 in the European Union states that have implemented the flat tax regime in comparison to the states with a progressive regime. The "Taxes in Europe" database was used for income tax rates, as well as the EUROMOD database for pre- and post-tax income inequalities (Gini index). A regression analysis was then performed to test whether the progressive tax system determines a reduction of income inequalities. The comparative graphic analysis showed that, on average, throughout the period analyzed, the Gini index of income inequality is lower in the states that have implemented a progressive tax system. However, the regression results indicate that the existence of a progressive tax regime could reduce the Gini index by only 0.021 , which suggests that the effect that a progressive tax system has on income inequalities can be considered quite limited. Basically we could conclude that the progressive tax system does not necessarily translate into greater redistribution if the collected revenues are too small to differentiate between individual and household incomes.

The study of [27] analyzes the fiscal, redistributive, and macroeconomic impact of introducing or reintroducing a progressive tax regime in a number of Central and Eastern European countries with flat-rate tax systems. The analysis uses microsimulation and macroeconomic models (QUEST model) and shows that a progressive tax system reduces income inequalities, but has a rather small effect on the macroeconomic level (GDP (Gross Domestic Product)) and employment. The size of the effects also depend on the specifics of the country and the characteristics of the tax system. The authors combine the EUROMOD model with the QUEST macroeconomic model to carry out an analysis of the redistributive and economic growth impact of the progressive tax reforms in countries with a 
flat-rate tax. Both models are combined by calibrating the QUEST model with parameters derived from EUROMOD in terms of personal income, tax structures, participation rates, and labor supply elasticity. The design of the tax reforms is first simulated in EUROMOD and then introduced in the QUEST model in order to obtain the macroeconomic effects (in particular the effects on prices, earnings, and employment), subsequently these effects are incorporated in the microsimulation model to realize the medium-term projections regarding income from personal income tax. Three scenarios are analyzed in the study. The first scenario aimed to assess the impact of the progressive tax measures without compensatory measures, and the other two scenarios also considered a series of alternative reforms to offset the impact on the GDP and employment.

\section{Data and Simulation Methodology}

The novelty of this paper consists in proposing a methodology that allows micro simulating the effects on inequality and poverty indicators of a progressive income taxation schedule to replace the actual flat-rate tax in Romania. To assure higher complexity to the ex-ante tax policy investigation, we intend to look at the revenue effects of the proposed changes as well.

Our simulations were based on the following main assumptions: (1) We use the pre-change income distribution of gross wages, (2) we apply the new progressive tax schedule on gross wages and estimate the new net wages, and (3) we disregard any potential behavioral change which could occur as a result of taxation change. The new estimated net wages are further used in the calculation of the post-change household disposable income. Our methodology is based on a microsimulation approach, using individual income data from the EU-SILC (European Union Survey on Income and Living Conditions). Through the survey, representative data is collected at the household and individual level for Romania, providing information on income amounts by sources of income, labor market status, education, and other socio-demographic characteristics. As the design of a tax system has a considerable impact on the distribution of income both at the household and individual level, we analyze the effects on household disposable income. Disposable income is calculated as market income plus social benefits minus direct taxes. Market income is defined as all earned income (wages), income from capital (dividends, rents, profits, etc.) and private transfers (remittances, alimonies, etc.). Disposable income is calculated at the household level, being further on equivalized using the OECD modified equivalence scale in order to account for family size and composition.

The survey covers around 7500 households and 17,200 individuals aged 16+ and collects annual data, the income reference period being the previous calendar year. For our study we use the 2017 survey with income data for 2016, but some adjustments are made in order to update the value of incomes from 2016 to 2019, using uprating factors for detailed income sources. However, the socio-demographic characteristics of the population remain constant at the year 2017, this being a drawback in our analysis, but still we could presume that major socio-demographic changes did not occur in two years. Other data adjustments we carried out refer to the consistency of declared relationships within a household, the allocation of income from non-respondents, the consistency between demographic, labor market, and income variables and the imputation of missing values for socio-demographic and labor market variables. The imputations were based on the values of other variables which were not missing, such as: missing age was imputed based on year of birth, missing current education was imputed based on age and the education system, missing economic status was imputed based on main income source and age, missing hours worked per month were imputed according to median employment income per hour, and so on.

Changing the tax schedule from a flat rate to a progressive one entailed two main decisions: one concerning the income thresholds and the other concerning the new tax rates. We simulated the changes only upon the taxation of employment income, although in Romania pensions above a threshold are taxed, but we left aside this issue because it would have complicated the interpretation of the resulted effects. The starting point for the setting of the thresholds has been the wage distribution, and we had a first attempt to link the thresholds with the quintile limits. However, during the process, 
we had to give up this strategy as the wage distribution which resulted from the EU-SILC micro-data is severely left skewed, over-representing low wage earners and under-representing high wage earners. Eventually, we decided to set the thresholds in connection with the average gross wage level, as an attempt to relate our scenarios to a wage distribution indicator. The details of the two proposed scenarios are shown in the Table 1.

Table 1. Progressive taxation schedule-proposed scenarios.

\begin{tabular}{cccc}
\hline Scenario 1 & \multicolumn{2}{c}{ Scenario 2 } \\
\hline Gross Wage & Tax Rate & Gross Wage & Tax Rate \\
\hline$\leq 0.5$ Av. Wage & $8 \%$ & $\leq 0.5$ Av. Wage & $8 \%$ \\
(0.5 Av. Wage, 0.75 Av. Wage] & $10 \%$ & (0.5 Av. Wage, 1.5 Av. Wage] & $10 \%$ \\
(0.75 Av. Wage, 1.5 Av. Wage] & $14 \%$ & (1.5 Av. Wage, 3 Av. Wage] & $16 \%$ \\
$>$ 1.5 Av. Wage & $18 \%$ & $>3$ Av. Wage & $20 \%$ \\
\hline
\end{tabular}

Sources: authors' own calculations based on European Union Survey on Income and Living Conditions (EU-SILC) data and EUROMOD model. Note: Av. is short for Average.

As it can be noted, both scenarios are based on a four-bracket system, the differentiation between the two scenarios resulting from the taxation of incomes higher than $75 \%$ of the average wage. In the first scenario, the tax rates range from 8 to $18 \%$, while in the second scenario the top rate extends up to $20 \%$. Compared to the $10 \%$ flat rate in place at the moment in Romania, both scenarios decrease the burden on low wage earners to $8 \%$. On the other hand, the first scenario keeps the actual tax rate for those who earn less than $75 \%$ of the average wage, while in the second scenario this bracket is extended to $150 \%$ of the average wage. In other words, in the first scenario the burden is shifted from low wage earners to middle wage earners, while in the second scenario it is the high wage earners who are more heavily taxed.

The tax burden for the low wage earners was dropped by two percentage points from the current $10 \%$ flat-rate tax in both scenarios, in order to assure a better fulfilment of social justice. In this manner, low wage earners will be taxed less than the rich ones, leading to an improvement of the living conditions for the individuals at the bottom of the distribution. The two scenarios mostly differ in the magnitude of the tax burden towards the middle and the high wage earners, the second scenario being slightly more shifted towards taxing higher wage earners. However, since both scenarios of progressive taxation follow the same principle of shifting the tax burden from those with relatively low incomes to those with high incomes, we might expect an improvement in terms of income inequality in both scenarios, but with slight differences in intensity.

The two scenarios have been implemented in turn and the effects of the changes on household disposable income have been analyzed. In doing so, we used the EUROMOD tax-benefit microsimulation model which allows for the estimation of tax liabilities and social benefits eligibilities using the policy rules for direct taxation and social benefits. The model is implemented for the EU 28 member states and enables the calculation, in a comparable manner, of the effects of taxes and benefits on household incomes and work incentives for the population of each country and for the EU as a whole. Our choice for using the EUROMOD model is based on two reasons. The first reason is that it allows for the simulation of different scenarios regarding taxation. Second, it can capture the effects of a higher net of tax income (when the tax burden is relieved) on the eligibility of means-tested benefits, as the amounts received as means-tested benefits can be reduced while income increases. We believe it is important to take into consideration these effects which could affect the effectiveness of lower taxation in poverty and inequality reduction, especially in the context of our paper as we attempt to investigate the income distribution effects of a progressive tax schedule.

The methodology has some limitations which have to be mentioned though, as they have implications on the results obtained. First, the structure of wage earners from survey data, broken down by wage level, is not fully consistent with administrative data especially at the tails, low wage earners being over represented detrimental to high wage earners. As a consequence, the poverty and 
inequality effects of a reform which decreases the burden on low wage earners could be overestimated. Or, a reform which increases the burden on higher wage earners could not seem very effective on the revenue side, while in reality it would collect considerable additional amounts to the state budget. We have to keep in mind that the EU-SILC survey is representative for households at the national level, not being aimed to reflect the structure of employees by any characteristic. Second, we estimate the first round, direct effects of taxation rules changes on household disposable income, disregarding any behavioral effects which may occur when taxation rules change. Third, we assume no tax evasion and full benefit take-up. And fourth, we use 2017 survey data on which we simulate the policies in place in 2019 as our baseline for simulations. However, we uprate the monetary variables to 2019 by average income growth rates for detailed income sources. The socio-demographic variables are kept constant to 2017.

\section{Main Results}

We have simulated the effects of the two proposed alternative progressive taxation scenarios according to the methodology presented in the previous section. The results were then compared with the baseline scenario consisting of a $10 \%$ flat-rate tax system. The baseline scenario reflects an estimation of the current position of Romania for the year 2019. Having a high Gini coefficient of 33.9 and an in-work poverty rate of $20.7 \%$ according to the EU-SILC database, Romania is among the countries with the highest level of inequalities and poverty in the EU. The economic and social inequalities in Romania have their roots in the transformations that took place at the level of the economy after the exit from the communist regime and the transition to a capitalist market economy. The polarization of incomes started with the privatization of state-owned companies when a concentration of resources was achieved within a small elite. The transition to a capitalist economy has further accentuated the level of inequalities, especially in the light of a poorly developed, fragmented and low-productivity agricultural sector, in which many households in Romania are still involved nonetheless. Basically, the economic evolution has created opportunities for some social categories, but at the same time it has reduced the prospects for others, depending on the level of education, age, area of residence, field of activity, etc.

Having this in mind, our aim consisted in investigating the impact of a change in the current Romanian personal income tax policy system from a $10 \%$ flat-rate taxation to one of two possible alternative progressive tax systems. The contribution of our impact evaluation analysis is two-fold. First, we focused on the social impact of such tax policy reform upon the labor market and, in particular, upon poverty and income inequality. Secondly, we turn towards the financial implications of the tax policy reform in order to investigate the impact upon the budget revenues collected from personal income tax in the two alternative scenarios.

Regarding the main social effects of this personal income tax policy reform upon poverty and income inequalities in Romania, throughout this paper we bring evidence of a modest, but still positive effect in favor of a progressive taxation system as compared to the flat-rate tax system. The changes that have occurred in the income distribution in comparison to the baseline scenario are illustrated in Table 2. The table shows the estimates of Gini coefficient of income inequalities and different at-risk-of poverty rates (total, in-work, and for employees) for the baseline distribution of incomes (pre-change of income taxation) and the percentage changes compared to the baseline observed for these estimates after the introduction of the progressive taxation schedule, in both scenarios analyzed.

The most relevant findings of our impact evaluation show a modest, but beneficial impact of progressive taxation on income inequalities in comparison to the $10 \%$ flat-rate personal income tax system that is currently applied in Romania. More precisely, the most notable change in the Gini coefficient of household income is observed in the first case scenario, where it drops by $0.53 \%$ in comparison to the baseline scenario. Similar decline in inequalities is also noticed in the case of the second scenario, but the drop in the Gini coefficient is only about $0.4 \%$. Our findings suggest that a change in the personal income taxation policy from a flat-rate tax to a progressive taxation system 
could bring slight improvements in terms of poverty and income inequalities, when the progressive taxation system assures a better consideration for the needs of poorer households as compared to the rest of the household income distribution, and especially to the richest households.

Moreover, in order to better quantify the spillover effects on the poverty rate was computed in three alternative manners. First, a total poverty rate was computed by identifying the percentage of the total population that has a disposable income lower than $60 \%$ of the median equivalized disposable income. Secondly, an employees' poverty rate was determined as the percentage of the employees that earn wages less than the poverty line, while thirdly, the in-work poverty rate was computed as the percentage of total employed individuals earning less than the poverty line.

Table 2. Micro-simulation results on poverty rate and income inequality.

\begin{tabular}{cccc}
\hline & Baseline & Scenario 1 & Scenario 2 \\
\hline & & \multicolumn{2}{c}{ Percentage change $(\%)$} \\
Total poverty rate & 25.8 & $-0.08 \%$ & $-1.1 \%$ \\
Employee poverty rate & 4.4 & $-1.60 \%$ & $-1.6 \%$ \\
In-work poverty rate & 20.7 & $-0.23 \%$ & $-0.7 \%$ \\
Gini coefficient & 33.9 & $-0.53 \%$ & $-0.40 \%$ \\
\hline Sources: authors' own caloulations based on EU-SILC
\end{tabular}

In general, there is a slight improvement in terms of poverty, with the most notable drop by approximately $1.6 \%$ registered in both progressive taxation scenarios when computing the employees' poverty rate. However, some distinctions between the effects of the two alternative progressive taxation scenarios are most noticed at total poverty rate level, where the second scenario leads to a more significant drop in the poverty rate by $1.1 \%$, while for the in-work poverty rate the differences are lower.

Small changes in both income distributions of households were noticed after computing the micro-simulations as compared to the baseline scenario. Although a positive influence of a progressive taxation system on income inequalities might be intuitive, the extent of its contribution is difficult to foresee as the tax rate structures affect each household income decile distinctly, making the cumulative effect less obvious to predict. The most important changes in the income distribution are generally noticed in the middle and higher deciles, as the average household disposable income increases more significantly from lower income decile to higher ones in the two progressive taxation scenarios. The only exception as expected is noticed in the last decile, where a slight reduction in the average household income is registered due to the proposed rise in the personal income tax rate levels. In the first scenario, the burden is placed also on middle wage earners together with high wage earners, compared to the second scenario where the higher wage earners are taxed more.

This leads to the lower average disposable income for the mid distribution in the first scenario compared to the second one. In terms of quintiles, the most notable changes in the household income distribution are registered in the third and the fourth quintiles, where the average household income is growing on a slow up rising trend. One notable particularity can be observed in the last quintile, where in the first scenario the average income is slightly dropping as compared to the baseline, but still slowly increasing in case of the second scenario, for it only affects a smaller number of the richest households. Also, we observe a dilution of the effects when shifting the analysis from decile to quintile distribution, practically we can no longer spot negative income effects for the richest household.

The three income distributions are plotted in Figure 1. Compared to the baseline scenario (the flat-rate tax of $10 \%$ ) the mean values of the income distributions are slightly higher in both cases of progressive taxation systems, with a bit higher values in the second scenario.

As it follows, we will look at the financial implications at governmental level of the two alternative progressive taxation scenarios and investigate the impact on the budget revenues from personal income tax. The changes that have occurred in the personal income tax budget revenues in comparison to the baseline scenario are illustrated in Table 3. One can observe that in both scenarios of progressive taxation systems, there is a general slightly negative effect upon the total income tax revenues computed 
as $\%$ of GDP, as it drops from $1.51 \%$ of GDP to $1.43 \%$ in the first scenario and a bit lower to $1.36 \%$ in the second scenario.

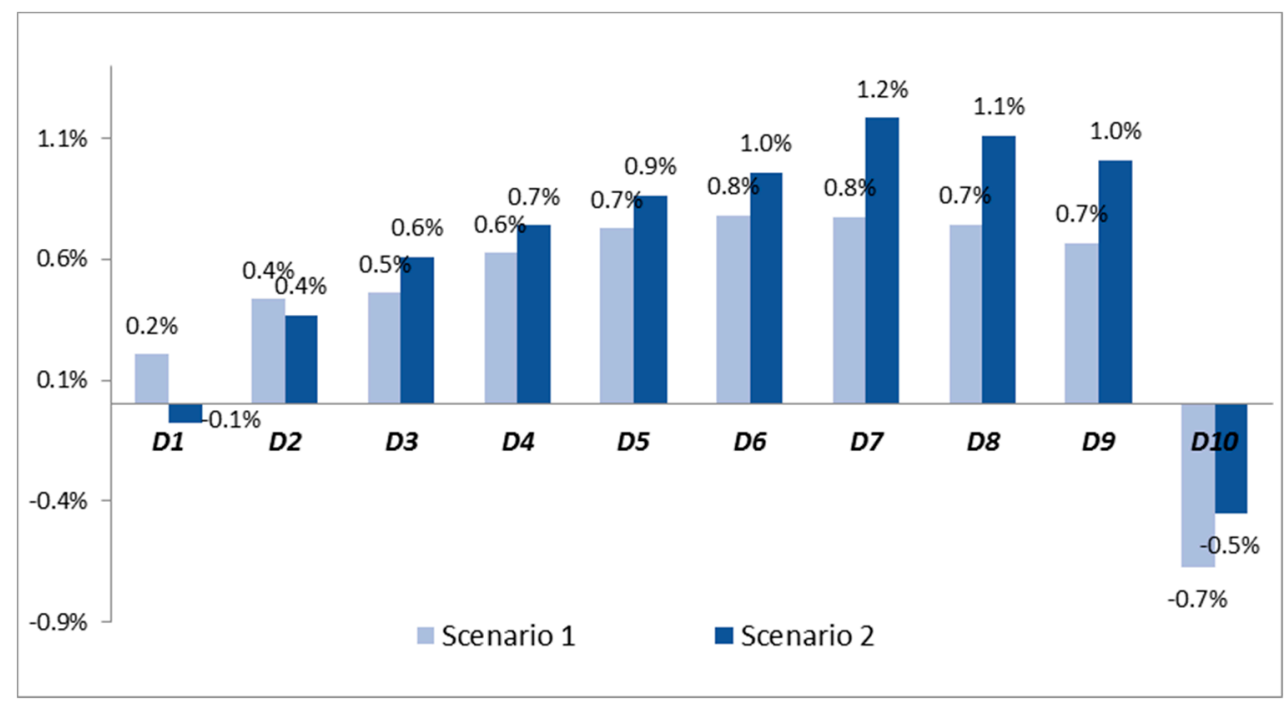

Figure 1. Disposable income change by deciles and \%. Note: Deciles were constructed based on equivalized household disposable income and the percentage changes show the changes in the two progressive taxation scenarios compared to the baseline. Source: authors' own calculations based on EU-SILC data and EUROMOD model.

Table 3. Micro-simulation results on average tax income rate ad budget revenues.

\begin{tabular}{cccc}
\hline & Baseline & Scenario 1 & Scenario 2 \\
\hline Average tax income rate & $10 \%$ & $9.5 \%$ & $9 \%$ \\
Budget revenues from personal income tax (\% of GDP) & $1.51 \%$ & $1.43 \%$ & $1.36 \%$ \\
\hline
\end{tabular}

Sources: authors' own calculations based on EU-SILC data and EUROMOD model.

In order to better explain the small drops in the personal income tax budget revenues that were obtained in this study, we have estimated the average income tax rates for the two alternative scenarios. We obtained an average income tax rate of about $9.5 \%$ in the first scenario and respectively of about $9 \%$ in the second scenario, which are both slightly lower as compared to the baseline flat-rate tax of $10 \%$. These values come to justify the drop in the total budget revenues collected from personal income taxes in both scenarios.

There are several reasons to explain the higher average tax rate obtained in the first scenario as compared to the second one. For instance, the most significant differences in terms of total income tax revenues might be generated by the fact that the persons earning between $75 \%$ and $150 \%$ of the average wage are being more heavily taxed in the first scenario (with a $14 \%$ tax rate) than in the second one, where they are being taxed by only $10 \%$. Moreover, although a $20 \%$ tax rate is applied in the second scenario for people earning more than three times the national average wage, their income tax contribution cannot exceed the amount collected from those belonging to the previous income brackets, as they are less represented in the wage distribution. Therefore, higher income tax revenues might have been, to some extent, expected to result from the first scenario than from the second one.

The negative outcome upon personal income tax budget revenues might not come as a total surprise, either, if we take a closer look at the initial household income distribution and the proposed levels of tax rates for the two progressive taxation scenarios. Keeping in mind the data limitations of the EU-SILC database, where the richest households are under-represented, we should look at these findings with caution. It is possible that although the sums collected from personal income tax for the first household income quintile are expected to shrink due to the introduction of lower 
tax rates applied for the poorest households, a reverse effect is also to be expected with the personal income taxes collected at the upper income quintile level. Estimating the total personal income tax budget revenues correctly requires conducting complex micro-simulations on a reliable database that correctly reflects the real household income distribution. In lack of such requirements, the ex-ante tax policy evaluation can still be of valuable importance, as it plays an informative role upon the multi-dimensional policy implications.

\section{Discussion and Conclusions}

Our paper has investigated the impact of a change in the current Romanian personal income tax policy system from a $10 \%$ flat-rate tax system to some alternative progressive taxation scenarios. The novelty of our paper mainly consists in the methodological approach that was elaborated in order to conduct an impact evaluation analysis upon poverty and income inequality on the one hand, as well as on the financial implications at governmental level upon the personal income tax budget revenues, on the other.

Through this ex-ante tax policy evaluation, we were able to bring evidence on both the benefits and the side effects of such tax policy reform, for the case of an Eastern European country, where the dispute on adopting a progressive tax system over a flat-rate tax one has recently come to the public's attention. On the one hand, we have brought empirical evidence of a modest but positive effect upon poverty rate and income inequalities in favor of a progressive taxation system as compared to the flat-rate tax system. Although the impact is modest, our findings highlight the beneficial impact of a progressive taxation on income inequalities in comparison to the current $10 \%$ flat-rate tax system applied in Romania. Our results are consistent with the international literature review [27,28], indicating that a change in the personal income tax policy regime is generally expected to be modest but positive, as the progressive tax-benefit system assures a better consideration for the needs of poorer households as compared to the rest of the household income distribution.

On the other hand, when considering the financial implications of the two alternative progressive taxation scenarios, we noticed a general slightly negative effect upon the total personal income tax revenues computed as \% of GDP. In order to better explain the small drops in the personal income tax budget revenues, we estimated the average income taxes for the two alternative scenarios and obtained slightly lower values as compared to the baseline.

Keeping in mind the data limitations of the EU-SILC database, where the distribution of wage earners is not fully consistent with administrative data at the tails, we might expect an over-representation of the low wage earners in detrimental to high wage earners. Therefore, the poverty and inequality effects of a reform could also be over-estimated in case of a decrease in the burden on low wage earners or the budgetary effects in terms of collection could be under-estimated in case of an increase in the burden on higher wage earners. Even under such caveats, our findings share valuable insights on the possible trade-off between the socio-economic benefits of a progressive taxation system expected upon poverty and income inequalities on the one hand, and the financial drawbacks upon the personal income tax budget revenues on the other hand.

Other limitations of our study refer to the microsimulation hypothesis, as we disregarded any behavioral effects which may occur when taxation rules change, and made the assumption of no tax evasion and full benefit take-up. Finally, we used 2017 survey data on which we simulated the policies in place in 2019 as our baseline for simulations. Although we uprated the monetary variables to 2019 by average income growth rates for detailed income sources, the socio-demographic variables were kept constant to 2017.

As a conclusion, we can state that the choice of the fiscal structure must take into account many factors, such as: the effects on the economic incentives, its fairness among persons with similar taxable capacity, its effects on the distribution between the rich and the poor, whether it is compatible with desirable international economic relations, and also based on its simplicity, ease of understanding and absence of excessive administrative costs. Moreover, a personal income tax policy reform should only 
be considered for implementation after a thorough ex-ante impact evaluation is conducted upon its multi-dimensional socio-economic implications.

In future research, we intend to overcome some of the EUROMOD tax-benefit microsimulation model limitations, by attempting to include behavioural responses to changes in income taxation. For that, we will have to identify patterns and differences in individuals' reactions for various categories by conducting longitudinal analysis of labour market transitions based on EU-SILC longitudinal microdata. Moreover, we intend to replicate the microsimulation analysis for other EU country case studies that are still currently implementing a flat personal income tax rate system, such as Bulgaria, Hungary, or the Baltic countries.

Author Contributions: Conceptualization, E.M. and M.E.P.; Methodology, E.M.; Software, E.M.; Validation, E.M.; Formal Analysis, M.E.P., M.D.V., L.S. and A.C.; Investigation, M.E.P., M.D.V., E.M., L.S. and A.C.; Resources, E.M.; Data Curation, E.M.; Writing-Original Draft Preparation, all authors; Writing-Review and Editing, E.M. and M.E.P.; Visualization, M.E.P., M.D.V., L.S. and A.C.; Supervision, E.M. and M.E.P.; Project Administration, M.E.P.; Funding Acquisition, M.E.P.

Funding: Nucleu Program funded by the Romanian Ministry of Research and Innovation (Project PN 19130103).

Acknowledgments: Part of this work was supported by the Nucleu Program funded by the Romanian Ministry of Research and Innovation (Project PN 19130103).

Conflicts of Interest: The authors declare no conflict of interest.

\section{References}

1. Diamond, P.A.; Saez, E. The Case for a Progressive Tax: From Basic Research to Policy Recommendations. J. Econ. Perspect. 2011, 25, 165-190. [CrossRef]

2. Meade, J.E. The Structure and Reform of Direct Taxation; Allen and Unwin: London, UK, 1978.

3. United Nations. Transforming our World: The 2030 Agenda for Sustainable Development; United Nations: New York, NY, USA, 2015.

4. Kalyva, A.; Princen, S.; Leodolter, A.; Astarita, C. Labour Taxation and Inclusive Growth. In Discussion Paper 084; Publications Office of the European Union: Luxembourg City, Luxembourg, 2018.

5. Begu, L.S.; David, N.; Dimian, G.C.; Alexandru, A.A. Current crisis and economic convergence in the EU. In Annals of Faculty of Economics; University of Oradea: Oradea, Romania, 2010; Volume 1, pp. 260-265.

6. Brys, B.; Perret, S.; Alastair, T.; O’Reilly, P. Tax Design for Inclusive Economic Growth. Available online: https: //www.oecd-ilibrary.org/taxation/tax-design-for-inclusive-economic-growth_5jlv74ggk0g7-en (accessed on 25 September 2019).

7. Bikas, E.; Subaciene, R.; Astrauskaitè, I.; Keliuotytè-Staniulènienè, G. Evaluation of the personal income progressive taxation and the size of tax-exempt amount in Lithuania. Ekonomika 2014, 93, 84-101. [CrossRef]

8. Dolenc, P.; Laporsek, S. Labour Taxation and Its Impact on Employment Growth. Manag. Glob. Transit. 2012, 10, 301-318.

9. Rogers, J.; Philippe, C. The Tax Burden of Typical Workers in the EU 28, 10th ed.; Institut Économique Molinari: Paris-Bruxelles, Paris, France, 2019; Available online: https://www.institutmolinari.org/wp-content/uploads/ sites/17/2019/07/tax_burden_EU_2019.pdf (accessed on 25 September 2019).

10. Leonida, I. Position of the Romanian tax system within the typology of tax systems. Financ. Stud. 2015, 3, 2015.

11. Doltu, C. The truth about flat-rate income tax in Romania. J. Community Posit. Pract. 2019, 19, 3-9. [CrossRef]

12. Roman, M.D.; Roman, M.; Talvan, M. A Macroeconometrical Model of Sustainable Fiscal Policy. Study Case Rom. Int. J. Trade Econ. Financ. 2012, 3, 73-77. [CrossRef]

13. European Commission. Taxation trends in the European Union; DG Taxation and Custom Union; Publications Office of the European Union: Luxembourg, 2019.

14. Husman, A.I. Taxation of employees in Romania in 2018. Changes and its results on the country's economy. Oradea J. Bus. Econ. 2018, 3, 46-55.

15. Nurja, I. Dynamics and Place of the Personal Income Tax in Albanian Economy. Acad. J. Interdiscip. Stud. 2016, 5, 25-34. 
16. Maer Matei, M.M.; Zamfir, A.M.; Mocanu, C. Labour Market Resilience-Comparative Evidence From Romanian Counties. J. Netw. Intell. Stud. 2018, 6, 59-66.

17. Lincaru, C.; Ciuca, V.; Pirciog, S. Romania's study case: National benchmarking counties regarding a sustainable economic growth profile using the World Bank JoGG's model. In Progress in Economics Research; Albert, T., Ed.; Nova Publishing: Hauppauge, NY, USA, 2017; Volume 38, ISBN 978-1-53611-106-4.

18. Filauro, S. The EU-Wide Income Distribution: Inequality Levels and Decompositions. Available online: https://ec.europa.eu/social/main.jsp?catId=738\&langId=en\&pubId=8096\&furtherPubs=yes (accessed on 23 September 2019).

19. Mihai, M.; Ţiţan, E.; Manea, D. Education and poverty. Procedia Econ. Financ. 2015, 32, 855-860. [CrossRef]

20. Conesa, J.C.; Krueger, D. On the optimal progressivity of the income tax code. J. Monet. Econ. 2006, 53, 1425-1450. [CrossRef]

21. Shapiro, R.J. Why Fairness Matters: Progressive Versus Flat Taxes. In Taxes \& The New Economy; Progressive Policy Institute: Washington, DC, USA, 1996.

22. Oishi, S.; Kushlev, K.; Schimmack, U. Progressive Taxation, Income Inequality, and Happiness. Am. Psychol. 2018, 73, 157-168. [CrossRef] [PubMed]

23. Mattesini, F.; Rossi, L. Monetary policy and automatic stabilizers: The role of progressive taxation. J. Money Credit Bank. 2012, 44, 825-862. [CrossRef]

24. Alessandrini, D. Progressive Taxation and Economic Stability. 2018. Available online: https://www.researchgate.net/profile/Diana_Alessandrini/publication/328234530_Progressive_taxation_ and_economic_stability/links/5bc08e6d92851c88fd6592a2/Progressive-taxation-and-economic-stability.pdf (accessed on 28 September 2019).

25. Gentry, W.M.; Hubbard, R.G. The effects of progressive income taxation on job turnover. J. Public Econ. 2004, 88, 2301-2322. [CrossRef]

26. Godar, S.; Paetz, C.; Truger, A. The scope for progressive tax reform in the OECD countries. A macroeconomic perspective with a case study for Germany. Rev. De l'OFCE 2015, 5, 79-117. [CrossRef]

27. Barrios, S.; Ivaškaitė-Tamošiūnè, V.; Maftei, A.; Narazan, E.; Varga, J. Progressive Tax Reforms in Flat Tax Countries, 2019, European Commission, JRC Working Papers on Taxation and Structural Reforms, No 02/2018. Available online: https://www.iser.essex.ac.uk/research/publications/working-papers/euromod/em2-19.pdf (accessed on 22 September 2019).

28. Lithuanian Free Market Institute. Progressive Taxes and Inequality. 2019. Available online: http://4liberty.eu/ progressive-taxation-and-inequality/ (accessed on 20 September 2019).

29. Salanié, B. The Economics of Taxation, 2nd ed.; MIT Press: Cambridge, MA, USA, 2011.

30. Evers, M.; de Mooij, R.; Van Vuuren, D. The Wage elasticity of Labour Supply: A Synthesis of Empirical Estimates. De Econ. 2008, 156, 25-43. [CrossRef]

31. OECD. Gender Equality in Education, Employment and Entrepreneurship: Final Report to the MCM 2012. Available online: http://www.oecd.org/employment/50423364.pdf (accessed on 28 September 2019).

32. Gechert, S.; Will, H. Fiscal Multipliers: A Meta Regression Analysis. Available online: https://www.econstor. eu/handle/10419/105964 (accessed on 24 September 2019).

33. Hall, R.E.; Rabushka, A. The Flat Tax, 2nd ed.; Hoover Institution Press: Stanford, CA, USA, 1995.

34. Paulus, A.; Peichl, A. Effects of Flat Tax Reforms in Western Europe on Equity and Efficiency. Available online: https://www.iser.essex.ac.uk/research/publications/working-papers/iser/2008-06.pdf (accessed on 26 September 2019).

35. Paulus, A.; Čok, M.; Hegedus, P.; Kump, N.; Lelkes, O.; Szivos, P.; Kralik, S.; Vork, A. Flat Tax Reform in Eastern Europe: Comparative Analysis of Alternative Scenarios in Estonia, Hungary and Slovenia, using EUROMOD. Available online: https://www.iser.essex.ac.uk/research/publications/working-papers/euromod/em9-09.pdf (accessed on 23 September 2019).

36. Slemrod, J. On the high-income Laffer curve. In Tax Progressivity and Income Inequality; Cambridge University Press: Cambridge, UK, 1994.

37. Sabirianova, K.P.; Buttrick, S.; Duncan, D. Global Reform of Personal Income Taxation, 1981-2005: Evidence from 189 Countries. Available online: https://papers.ssrn.com/sol3/papers.cfm?abstract_id=1423344 (accessed on 25 September 2019).

38. Autor, D.H.; Katz, L.F.; Kearney, M.S. The Polarization of the US Labour Market. Am. Econ. Rev. 2006, 96, 189-194. [CrossRef] 
39. Goos, M.; Manning, A.; Salomons, A. The Polarization of the European Labor Market. Am. Econ. Rev. Pap. Proc. 2009, 99, 58-63. [CrossRef]

40. Helpman, E.; Itskhoki, O.; Redding, S.J. Inequality and Unemployment in a Global Economy. Econometrica 2010, 78, 1239-1283.

41. Koske, I.; Fournier, J.-M.; Wanner, I. Less Income Inequality and More Growth-Are They Compatible? Part 2. The Distribution of Labour Income. Available online: https: //www.oecd-ilibrary.org/economics/less-income-inequality-and-more-growth-are-they-compatiblepart-2-the-distribution-of-labour-income_5k9h2975rhhf-en (accessed on 25 September 2019).

42. OECD. Reducing Income Inequality While Boosting Economic Growth: Can It Be Done? In Economic Policy Reforms: Going for Growth; OECD Publishing: Paris, France, 2012; pp. 181-202.

43. Piketty, T.; Saez, E. Income inequality in the United States, 1913-1998. Q. J. Econ. 2003, 118, 1-41. [CrossRef]

44. Godechot, O. Is finance responsible for the rise in wage inequality in France? Socio Econ. Rev. 2012, 10, 447-470. [CrossRef]

45. Adukonu, S.; Ofori-Abebrese, G. Relative Impact of Various Taxes on Poverty in Ghana. Mediterr. J. Soc. Sci. 2016, 7, 150-161.

46. Joumard, I.; Pisu, M.; Bloch, D. Tackling income inequality: The role of taxes and transfers. OECD J. Econ. Stud. 2012, 37-70. [CrossRef]

47. Kamin, D. Reducing Poverty, not Inequality: What Changes in the Tax System can Achieve. Available online: https://papers.ssrn.com/sol3/papers.cfm?abstract_id=2234519 (accessed on 25 September 2019).

(C) 2019 by the authors. Licensee MDPI, Basel, Switzerland. This article is an open access article distributed under the terms and conditions of the Creative Commons Attribution (CC BY) license (http://creativecommons.org/licenses/by/4.0/). 